\title{
Basic Psychological Needs, Depression, and Life Satisfaction among the Elderly
}

\author{
Aileen Joyce J Lim ${ }^{1}$, Mary Rachelle R Wapano, Ph.D ${ }^{2}$ \\ ${ }^{I}$ Mindanao State University at Naawawan \\ ${ }^{2}$ Xavier University - Ateneo de Cagayan
}

\begin{abstract}
This study examined the relationship between basic psychological needs and satisfaction with life among the elderly in rural area in the Phillipines.
\end{abstract}

Findings revealed that elderly indicated that their basic psychological needs are generally satisfied:. The results show that of the psychological needs autonomy $(\mathrm{M}=4.82, S D=0.94)$, competence $(M=4.94, S D=1.08)$, and relatedness $(M=5.46$, $S D=1.03)$ are generally satisfied.

Additionally, respondents reported general satisfaction with life mean score $(M=25.90, S D=0.37)$. The respondents of this study report that they are generally satisfied with their quality of life, achievement, and past experiences

This study also revealed that basic psychological needs do not significantly predict life satisfaction. It is recommended that other factors be investigated which could potentially predict life satisfaction. Recommendation

Keywords: elderly, basic psychological needs, depression, satisfaction with life, autonomy, competence, relatedness

\section{INTRODUCTION}

$\mathrm{T}$ The ultimate goal as people age is to maintain quality of life with special emphasis on satisfying the psychological needs of the elderly since the definition of what constitutes "good health" in older age varies across studies. A study conducted by Ward, Barnes and Gahagan (2012) pointed out that the things that elderly people identify as essential to their well-being include having a role identity, relationships, the possibility of enjoyment, autonomy, security and the potential for personal growth.

According to World Health Organization (2015), there are around five key domains of functional ability that are essential for older people to meet their basic needs; as for being autonomous-learn, grow and make decisions; be mobile; in terms of relatedness - build and maintain relationships; and in terms of competence - being mobile and contribute. These abilities are essential to enable older people to do the things that they value.

In developing countries like the Philippines, the quality of life of older persons depends largely on the family support system. The family and the home are pivotal points of exchange of support and care among older and younger generations (Ogena, 2006). In a study of Glaser, Agree \& Costenbader (2004), the elderly in the Philippines were most likely to receive financial and material support from their children.
However, according to de Leon (2014) elderly welfare should not be limited to but should go beyond economic provisions, global discourses and international movements on elderly concerns now emphasize the realization of "quality of life" and "active aging" as an integral part of the elderly population's human rights, and of social development in general.

Mental illness prevention is crucial among older adults and social support has a significant part for their well-being. To safeguard one's self in the probability of emergent depressive symptoms, loneliness and isolation is to have a social support system or establishing a close and intimate social relation that can be considered as a protective barrier against psychological illnesses (Vega, Del-Villar, Saucedo, and Alvarado, 2017). Given the state of aging, the study examined the

the relationship between the satisfaction of the basic psychological needs (competence, relatedness and autonomy). This study addresses the following research questions:

1. What are the the basic psychological needs of the elderly?

2. What is the level of satisfaction with life among the elderly?

3. Which among the basic psychological needs (predict life satisfaction among the elderly?

The study was guided by Edward Deci and Richard Ryan's self-determination theory (Deci \& Ryan, 2019). SDT has six mini-theories and the present study was grounded on one of its mini-theories the Basic Psychological Needs Theory (BPNT), which summed up three psychological needs:

Autonomy is the need to make choices according to one's own free-will and to set life-goals and being able to accomplish those goals. Competence is the need of an individual to be able to feel operational to execute tasks and roles in relation to the different settings in his surroundings). Relatedness is the need to feel socially and emotionally associated to others in a meaningful way(Legault, 2017, pg. 2).

Basic Psychological Needs Theory (BPNT) is the fourth mini-theory and expounds the idea of the development of psychological needs and its association to an individual's psychological health and well-being (Deci and Ryan, 2019). BPNT contends that psychological wellness and optimum 
performance is grounded on autonomy, competence and relatedness.

In order for the elderly to continue doing the things that is of significance to them, is to be able to satisfy these basic needs that consists of discovering new ventures, the opportunity for development and being able to still have the freedom of choice; still being active; establishing and sustaining relationships, and being able to contribute in the community or environment (Vega, Angel, Robledo and Markides, 2019)

The results could contribute to the literature of the well-being of the elderly specifically basic psychological needs and the relationship with life satisfaction.

\section{RESEARCH METHODOLOGY}

This is a descriptive correlational study. This study was conducted in the a rural area in the Philippines To date, no formal studies had been done to examine the mental health and psychosocial status of the elderly in Naawan. Additionally, the current programs that address the elderly's psychosocial needs are informal and cannot be described as sustainable. There is evidently a need to assess the psychological well-being of the elderly to be able to provide scientific data in the creation of psychosocial programs for the elderly aimed at addressing their psychological needs.

The participants of the study consisted of elderly individuals aged 60 to 84 years. In this study, the diversity in old age was recognized: The elderly respondents were classified as young-old, middle-old and old-old.

The following procedures were followed to gather the needed data: The elderly participants were grouped by batch of ten (10) so that the researcher was able to monitor the responses of the survey questionnaire and questions was addressed personally. The participants were scheduled in advance on what day they would choose (Monday to Saturday) for the data gathering procedures.

The questionnaires for the Basic Psychological Needs Scale (BPNS), and the Satisfaction with Life Scale (SWLS) were presented to research participants. The questionnaires were translated in a local dialect. A sample of 197 respondents was drawn from the elderly population comprising of male and female elderly with age range from 60 years old to the oldest respondent 84 years of age. Informed consent was sought from the research participants.

Descriptive statistics were used to identify the basic psychological need and the level of life satisfaction. Linear regression were also used to test the significance relationship between the basic psychological needs and satisfaction with life.

The instruments used in this study were the following: Basic Psychological Needs Scales, and Satisfaction with Life Scale. Permission to use was granted to use these questionnaires in this study, The scales used were translated in a local dialect.The faithful translation approach was used in the study. Faithful translation attempts to produce the precise contextual meaning of the original within the constraints of the target language grammatical structures (Newmark, 1988; Ordudari, 2007).

Basic Psychological Needs Scale (BPNS), form three subscale scores, one for the degree to which the person experiences satisfaction of each of the three needs.

The Satisfaction with Life Scale (SWLS) . The SWLS is a 7-point Likert style response scale. The possible range of scores is 5-35, with a score of 20-24 representing an average score on the scale. If we divide by the number of questions, rather than use the summed aggregate score, then the cutoffs below will be used (Diener, 2006).

To determine which among the basic psychology needs (autonomy, competence and relatedness) predicts depression, linear regression analysis was used.

To assess the level of satisfaction of the basic psychological needs of the elderly in terms of autonomy, competence and relatedness, the Basic Psychological Needs Scale was used and authored by Edward L. Deci and Richard M. Ryan (2000) - the authors also of self-determination theory. The English version of the tool had been pilot-tested locally to 30 elderly participants and obtained a good reliability index when it comes to autonomy $(\mathrm{R}=0.75)$, competence $(\mathrm{R}=0.73)$ and relatedness $(\mathrm{R}=0.83)$. (Tajrishi, Besharat, Pourbohlool, and Larijani, 2011)

To assess the satisfaction with life among the elderly, the Satisfaction with Life Scale was used developed by Ed Diener and colleagues (Diener et al, 1985; Pavot \& Diener, 1993). The scale was developed as a measure of the judgmental component of subjective well-being (SWB). The analysis of the scale's reliability showed good internal consistency $(\mathrm{R}=0.74)$ administered to Mexican adults 50 years of age or older (López-Ortega, Torres-Castro, and Rosas-Carrasco, 2016).

\section{Ethical considerations}

Informed consent was sought from research partcipiants. They were informed about the nature of the research study, and were informed that their participation is completely voluntary and can wirthdraw at any time in the duratio of the research.

The participants were informed that all the data, records and results of this study was kept confidential. Electronic information, these was coded and secured using a password protected file

The anonymity and privacy of the participants were protected. and did not collect/require personal information such as names, birthdates, phone numbers and physical or email addresse. Numbers was assigned on the completed questionnaires for each of the participants who was asked. 
The participants personal data cannot be identified in the aggregated data.

\section{RESULTS}

\section{Psychological Needs of the Elderly}

The table shows the level of psychological needs among the elderly respondents. This table shows the overall mean score of the scaled responses of 197 elderly respondents when asked questions concerning their basic psychological needs of autonomy, competence, and relatedness. From the table, it can be inferred that the satisfaction for the psychological need for relatedness was most satisfied basic psychological need yielded the highest result $(M=5.87$, $S D=1.03$ ); where as need for autonomy revealed to have the lowest mean score $(M=4.78, S D=0.94)$.

Table 1: Overall Mean Score of the Basic Psychological Needs of the Elderly

\begin{tabular}{|c|c|c|c|}
\hline $\begin{array}{c}\text { Basic Psychological } \\
\text { Needs }\end{array}$ & $\begin{array}{c}\text { Computed } \\
\text { Mean } \\
\text { score }\end{array}$ & SD & $\begin{array}{c}\text { Responses based on } \\
\text { how "satisfied" each } \\
\text { basic psychological } \\
\text { needs were for the } \\
\text { respondents }\end{array}$ \\
\hline Need for Autonomy & 4.82 & 0.94 & $\begin{array}{c}\text { Satisfied some of the } \\
\text { time }\end{array}$ \\
\hline $\begin{array}{c}\text { Need for } \\
\text { Competence }\end{array}$ & 4.94 & 1.08 & $\begin{array}{c}\text { Satisfied some of the } \\
\text { time }\end{array}$ \\
\hline $\begin{array}{c}\text { Need for } \\
\text { Relatedness }\end{array}$ & 5.46 & 1.03 & $\begin{array}{c}\text { Satisfied most of the } \\
\text { time }\end{array}$ \\
\hline
\end{tabular}

The psychological need of relatedness is shown to being satisfied most of the time. The elderly respondents report that felt that the they feel cared for by their family and significant others. people in their lives care about them $(M=6.27, S D=1.31)$ This result suggest that the elderly relate positively with others and this become more evident with age (Gold \& Arbuckle, 1992).

The same table shows that, in terms of the psychological need for competence, respondents report that they have a sense of accomplishment from the projects they are currently doing. $(M=5.65, S D=1.62)$. They also report a level of frustration as they have limited opportunities to express their capabilities $(M=3.90, S D=1.94)$. This may be related to the functional limitations which places some restrictions in their ability to attending or completing tasks.

In terms the basic psychological need for autonomy: The respondents report that the need for expression of their ideas and opinions are generally satisfied.

As for the basic psychological need for autonomy, one of the aspects for autonomy in which the respondents report that the need to be able to freely express ideas and opinions were most of the time satisfied $(M=5.67, S D=1.61)$. Respondents also report that they are uncomfortable receiving instructions from adult children or significant other on their daily care $(M=2.93, S D=1.98)$. Acosta (2020) reported similar results: that $77 \%$ of adult children are struggling with aging parents who refuse help and are resistant about taking the adult children's advice. The need for autonomy is expected to decrease during old age with the onset of functional and physical limitations (Dunlop, Manheim, Sohn, Liu, \& Chang, 2002). The elderly, especially if with serious health condtion need the physical care of the family and caregivers. This reduced physical capability and the need to depend contributs to a reduced sense of independence and self-reliance.

\section{Life Satisfaction among the Elderly}

The table below shows the level of life satisfaction among the elderly.

Table 2 Mean Scores of the level of Satisfaction with Life of the Elderly Respondents based on Age

\begin{tabular}{|c|c|c|c|c|}
\hline Age/Sub-groups & $\mathrm{N}$ & $\begin{array}{c}\text { Mean } \\
\text { Scores }\end{array}$ & SD & Interpretation \\
\hline $60-65$ & 77 & 25.86 & 5.39 & Satisfied \\
\hline $66-70$ & 89 & 25.60 & 4.95 & Satisfied \\
\hline $71-84$ & 31 & 26.32 & 5.14 & Satisfied \\
\hline Overall mean & & 25.90 & 0.37 & Satisfied \\
\hline
\end{tabular}

$N=197$

Across the three age groups, respondents reported general satisfaction with life mean score $(M=25.90$, $S D=0.37$ ). The respondents of this study report that they are generally satisfied with their quality of life, achievement, and past experiences. Gana, Bailly, Saada, Joulain, and Alaphilippe (2013) coined the phrase "paradox of well-being" when the elderly respondents shown an increase in life satisfaction as they age. It then appearns that aging and happiness have a positive linear relationship. Additionally Kutubaeva (2019) shows that despite the stereotypic belief that the elderly are unhappy, age does not appear to be a strong predictor of subjective well-being (Staudinger and Fleeson 1996) and its effects to well-being are found to be indirect rather than direct (Meléndez, Tomás, Oliver, \& Navarro, 2009).

\section{Basic psychological needs Predictor of Life satisfaction}

A simple linear regression was also used to predict satisfaction with life from the basic psychological needsautonomy, competence and relatedness. The results show that autonomy did not significantly predict life satisfaction scores, $(\beta=.03, t(195)=.44), \mathrm{p}<.05$ The basic psychological need of autonomy did not justify a significant amount of the variance in life satissfaction, $\mathrm{F}(1),(195)=.19, \mathrm{p}=.66, \mathrm{R}^{2}=.001, \mathrm{R}^{2}$ adjusted $=-.004, \mathrm{p}<.05$. The regression coefficient $(\mathrm{B}=.03,95 \%$ CI [$0.12,0.19])$ indicated that as the level of satisfaction on the basic psychological needs for autonomy increases, on average, the level of life satisfaction scores increases by 0.03 points. The value indicates that $0.1 \%$ of the variance in the level of satisfaction with life is explained by its linear relationship with the basic psychological needs when it comes to autonomy. 
Table 3: Linear Regression Analysis: Basic Psychological Needs (Autonomy) and Satisfaction with Life

\begin{tabular}{|c|c|c|c|c|c|}
\hline Source & $B$ & $S E B$ & $\beta$ & $t$ & $p$ \\
\hline Autonomy & .03 & .08 & .03 & .44 & .66 \\
\hline Competence & .08 & .07 & .08 & 1.16 & .25 \\
\hline Relatedness & .13 & .07 & .13 & 1.89 & .06 \\
\hline
\end{tabular}

a. Dependent Variable: Satisfaction with Life ${ }^{*} p<.05$

In this study, elderly respondents report that were able to freely express their ideas and opinions $(M=5.73$, $S D=1.60$ ) which was most of the time satisfied and the elderly feels that they can pretty much be comfortable being by themselves in daily situations $(M=5.33, S D=1.86)$. It appears that even as older people might not have the ability to act on their choices, they still can express their preferences and are capable in making decisions (Leivesley, 2018).

The needs of competence did not significantly predict life satisfaction scores, $\beta=.08, \mathrm{t}(195)=1.16, \mathrm{p}<.05$ The basic psychological need of competence did not justify a significant amount of the variance in life satisfaction, $\mathrm{F}(1),(195)=1.34, \mathrm{p}=.25, \mathrm{R}^{2}=.007, \mathrm{R}_{\text {adjusted }}^{2}=.002, \mathrm{p}<.05$. The regression coefficient $(\mathrm{B}=.08,95 \%$ CI $[-0.06,0.21])$ indicated that as the level of satisfaction on the basic psychological needs for competence increases, on average, the level of life satisfaction scores increases by 0.08 points.

The value indicates that $0.7 \%$ of the variance in the level of satisfaction with life is explained by its linear relationship with the basic psychological needs when it comes to competence.

As for the basic psychological needs of relatedness, the need did not significantly predict life satisfaction scores, $(\beta=.13, t(195)=1.89), p<.05$ The basic psychological need of relatedness did not justify a significant amount of the variance in life satisfaction, $\mathrm{F}(1),(195)=3.58, \mathrm{p}=.06, \mathrm{R}^{2}=.018, \mathrm{R}^{2}$ adjusted $=.013, \mathrm{p}<.05$. The regression coefficient $(\mathrm{B}=.67,95 \% \mathrm{CI}$ [$0.01,0.27])$ indicated that as the level of satisfaction on the basic psychological needs for relatedness increases, on average, the level of life satisfaction scores increases by 0.67 points The value indicates that $1.8 \%$ of the variance in the level of satisfaction with life is explained by its linear relationship with the basic psychological needs when it comes to relatedness.

The results in the linear regression indicated basic psychological needs (autonomy, competence and relatedness) did not significantly predict life satisfaction among the elderly respondents: $(p=0.66)$, competence $(p=0.25)$ and relatedness $(\mathrm{p}=0.06)$ were not significant predictors in the model.

The need to establish close relationships with others especially the family members as a predictor of life satisfaction has been investigated in research. Although in this research, all three psychological needs did not significantly predict life satisfaction level, several researches have consistently investigated that sense of autonomy and relatedness positively correlates with life satisfaction. In another study conducted by Banjare, Dwivedi, and Pradhan (2015), it was revealed that cognitive health was the most influential factor in determining life satisfaction among the elderly group in India. Individual social support also plays an influential role in life satisfaction among the rural elderly. Significantly lower scores in life satisfaction and those with low score of activities in daily living (ADL) also reported lower perceived life satisfaction. Another study conducted by Chen (2001) revealed social demographic variables such as living arrangement, income decrease, and level of activity participation have profound impact on perceived life satisfaction among the elderly in the country of Taiwan. In a study by Dong, Larsson, Dragioti, Bernfort, Levin, Gerdle (2020) further investigated that chronic pain significantly affect the perceived life satisfaction among the older people.

People who have high score on life satisfaction tend to have close and supportive family and friends, however, those individuals who do not have close friends and family felt more likely to be dissatisfied. People tend to lose close social ties through discord or conflict or through death of a loved one that can cause dissatisfaction with life, and it may take some time for the person to overcome from the loss (Diener, 2006).

Performance of an important role such as a homemaker or grandparent, accomplishment at work or school is another component that influences the life satisfaction of most people. When an individual enjoys his or her work, promotes life satisfaction. Whereas when work is not fulfilling, or is a poor fit with the person's strengths is shown to be related to low life satisfaction. When a person has significant goals to achieve, and could not seem to achieve those goals to make adequate progress towards them, this can also lead to life dissatisfaction (Diener, 2006).

Studies show other sources that can impact to life satisfaction - such as religious or spiritual life, learning and growth, and leisure. For many individuals these are sources of satisfaction. Health is also named as another source of life satisfaction. Most individuals have a certain level of awareness on what that would lead to lfe satisfaction. A person's disposition, a general tendency to be happy or unhappy, can is also shown to have an influence to life satisfaction (Diener, 2006).

Life satisfaction could then be influenced by other contextual and experiential, social demographic variables, other than basic psychological needs.

Given the results of this study that basic psychological needs do not significantly predict life satisfaction, it is recommended that other factors be investigated which could potentially predict life satisfaction. Demographic variables such as educational attainment, pension income, living arrangements and health status may also be taken into 
consideration in future studies as these may also influence life satisfaction.

Further validation research may also be done to validate the translated measures Basic Psychological Needs Scale and Life Satisfaction scale, to consider cultural and geographical context.

\section{REFERENCES}

[1] Ackerman, C. (2018). Life satisfaction theory and four contributing factors. Retrieved from https://positivepsychologyprogram.com/life-satisfaction/

[2] Agrawal, S. (2012) Effect of Living Arrangement on the Health Status of Elderly in India: Findings from a National Cross Sectional Survey. Asian Population Studies, 8, 37-41. https://doi.org/10.1080/17441730.2012.646842

[3] Alma M. L. Au, Stephen C. Y. Chan, H. M. Yip, et al., "AgeFriendliness and Life Satisfaction of Young-Old and Old-Old in Hong Kong," Current Gerontology and Geriatrics Research, vol. 2017, Article ID 6215917, 10 pages, 2017. https://doi.org/10.1155/2017/6215917.

[4] Anand, Paul (2016) Happiness, well-being and human development: the case for subjective measures. Human Development Report background paper, 2016. United Nations Development Programme, New York, USA. Retrieved from http://eprints.lse.ac.uk/83551/1/Anand_Happiness\%20wellbeing_2017.pdf

[5] Ardelt, M. (1997). Wisdom and life satisfaction in old age. Journal of Gerontology: Psychological Sciences, Vol. 52B, No.1, 15-27. Retrieved from http://users.clas.ufl.edu/ardelt/Wisdom_and_life_satisfaction_in_o ld_age.pdf

[6] Aquino, J. A., Russell, D. W., Cutrona, C. E., \& Altmaier, E. M. (1996). Employment status, social support, and life satisfaction among the elderly. Journal of Counseling Psychology, 43(4), 480489. https://doi.org/10.1037/0022-0167.43.4.480

[7] Banjare, P., Dwivedi, R. \& Pradhan, J. (2015). Factors associated with the life satisfaction amongst the rural elderly in Odisha, India. Health Quality of Life Outcome 2015 https://doi.org/10.1186/s12955-015-0398-

[8] Boyle, G. (2004). Facilitating choice and control for older people in long-term care', Health and Social Care in the Community, Vol. 12, no. 3, pp. 212-213.

[9] Calvisi, D. \& Dibble, J. (2011). Well-being in older adults from three different cultures. Art and Science Aging Conference. Grand Valley State University. Retrieved 2/28/2019 from https://www.gvsu.edu/gerontology/past-student-posters-11.htm

[10] Cao, Y., Krause, J. S., Saunders, L. L., \& Clark, J. M. (2015). Impact of marital status on 20-Year subjective well-being trajectories. Topics in spinal cord injury rehabilitation, 21(3), 20817. Retrieved 3/15/2019 from https://www.ncbi.nlm.nih.gov/pmc/articles/PMC4568083/. DOI: 10.1310/sci2103-208

[11] Chen, C. (2001). Aging and Life Satisfaction. Social Indicators Research, 54(1), 57-79. from http://www.jstor.org/stable/27526928

[12] Cohen, S. (1992). "Stress, social support, and disorder," in The Meaning and Measurement of Social Support, eds H. O. F. Veiel and U. Baumann (New York, NY: Hemisphere), 109-124

[13] Cohen, S. (2004). Social relationships and health. Am. Psychol. 59, 676-684. doi: 10.1037/0003-066X.59.8.676

[14] Deci, E. L., Ryan, R. M., \& Koestner, R. 1999. A meta-analytic review of experiments examining the effects of extrinsic rewards on intrinsic motivation. Psychological Bulletin, 125: 627-668. Retrieved

from http://citeseerx.ist.psu.edu/viewdoc/download?doi=10.1.1.588.582 $1 \&$ rep=rep1\&type=pdf

[15] Deci, E. L., \& Ryan, R. M. 2000. The "what" and "why" of goal pursuits: Human needs and the self-determination of behavior. Psychological Inquiry, 11: 227-268. Retrieved from
https://selfdeterminationtheory.org/SDT/documents/2000_DeciRy an_PIWhatWhy.pdf

[16] Deci, E. L., \& Ryan, R. M. (2002). Handbook of selfdetermination research. Rochester, NY: The University of Rochester Press.

[17] Deci, E. L., \& Ryan, R. M. (2019). Self-determination theory. Retrieved from http://selfdeterminationtheory.org/de Leon, A. (2014). The quality of life of the elderly Filipino in selected cities and provinces. First multipartite regional meeting on the financial security of older women in east and southeast Asia. Retrieved from www.tsaofoundation.org

[18] Diener, E., Emmons, R. A., Larsen, R. J., \& Griffin, S. (1985). The satisfaction with life scale. Journal of Personality Assessment, 49, $1 . \quad$ Retrieved from http://labs.psychology.illinois.edu/ ediener/Documents/DienerEmmons-Larsen-Griffin_1985.pdf

[19] Diener, E., Suh, E.H., Lucas, R.E., \& Smith, H.L. (1999). Subjective well- being: Three decades of progress .Psychological Bulletin, 125, 276-302. Retrieved from https://media.rickhanson.net/Papers/SubjectiveWellBeingDiener.pdf

[20] Diener, E., \& Tay, L. (2016). New frontiers: societal measures of subjective well-being for input to policy. In L. Bruni \& P.L. Porta (Eds.), Handbook of research methods and applications in happiness and quality of life, (35-52). Northhampton, MA: Edward Elgar Publishing.

[21] Dong, H. J., Larsson, B., Dragioti, E., Bernfort, L., Levin, L. Å., \& Gerdle, B. (2020). Factors Associated with Life Satisfaction in Older Adults with Chronic Pain (PainS65+). Journal of pain research, 13, 475-489. https://doi.org/10.2147/JPR.S234565

[22] Dulock, H. (1993). Reseearch design: descriptive research. Journal of Pediatric Oncology Nursing.Vol 10, No. 4. Retrieved from https://journals.sagepub.com/doi/abs/10.1177/1043454293010004 06? journalCode $=$ jpob

[23] Dunlop, D.D., Manheim, L.M., Sohn, M-W., Liu, X., Chang, R.W. (2002). Incidence of functional limitation in older adults: the impact of gender, race, and chronic conditions. Arch Phys Med Rehabil; 83:964-71.

[24] Frey BS, Stutzer A (2002) Happiness and Economics. Princeton University Press: Princeton and Oxford.

[25] Gagne, M., \& Deci, E. L. (2014). The History of SelfDetermination Theory in Psychology and Management. In M. Gagne (Ed.), The Oxford Handbook of Work Engagement, Motivation, and Self-Determination Theory (pp. 1-9). (Oxford Library of Psychology). United Kingdom: Oxford University Press. Retrieved from http://reflectd.co/2015/03/19/the-threemost-basic-psychological-needs-and-why-we-need-to-satisfythem/

https://books.google.dk/books?id=mPOHAwAAQBAJ\&printsec $=$ f rontcover\&dq=the+oxford+handbook+of+work+engagement+mot ivation+and+self-

determination \&hl=da\&sa $=$ X\&ei $=J 50 K V Y L d G 4$ esPO-

MgegN\&ved=0CB8Q6AEwAA\#v=onepage \&q=the $\% 20$ oxford $\% 2$ Ohandbook $\% 20$ of $\% 20$ work $\% 20$ engagement $\% 20$ motivation $\% 20$ an $\mathrm{d} \% 20$ self-determination $\& \mathrm{f}=$ false

[26] Gagnon, D. (2019). Getting your psychological needs met. Retrieved from https://www.montrealcbtpsychologist.com/storage/app/media/getti ng-your-psychological-needs-met.pdf

[27] Gana, K., Bailly, N., Saada, Y., Joulain, M., Alaphilippe, D. (2013). Does Life Satisfaction Change in Old Age: Results From an 8-Year Longitudinal Study, The Journals of Gerontology: Series B, Volume 68, Issue 4, Pages 540552, https://doi.org/10.1093/geronb/gbs093.

[28] Glaser, K., Agree, E., \& Costenbader, E. (2004). The Effects of Fertility Decline on Family Structure and Support for Older Persons in Latin America and Asia. Presented at the Aging and Health in Asia Project Meeting , Singapore May 28, 2004. Retrieved http://aha.psc.isr.umich.edu/research/singapore2004/agree2.pdf 
[29] Gold, D. P., \& Arbuckle, T. Y. (1992). Interactions between personality and cognition and their implications for theories of aging. In E. A. Lovelace (Ed.), Aging and cognition: Mental processes, self-awareness, and interventions (pp. 351-377). Amsterdam: North-Holland.

[30] Hmel, B. A., \& Pincus, A. L. (2002). The meaning of autonomy: On and beyond the interpersonal circumplex. Journal of Personality, 70(3), 277-310. doi: 10.1111/1467-6494.05006

[31] Kozerska, A. (2015). Life satisfaction among people aged 60 and over, participating in restricted social networks in Poland: Related variables. Problems of Education in the $21^{\text {st }}$ Century. Vol. 67, 29$39 . \quad$ Retrieved from http://www.scientiasocialis.lt/pec/node/files/pdf/vol67/2939.Kozerska_Vol.67_PEC.pdf

[32] Kutubaeva, R. Zh. (2019). Analysis of life satisfaction of the elderly population on the example of Sweden, Austria and Germany. Population and Economics 3(3): 102116. https://doi.org/10.3897/popecon.3.e47192

[33] Lee, J., Cho, D., \& Suh, Y. J. (2017). Purpose and meaning in life and job satisfaction among the aged. The International Journal of Aging \& Human Development, 85(4), 377402. https://doi.org/10.1177/0091415016688305

[34] Legault, L. (2017). Self-Determination Theory. In: ZeiglerHill V., Shackelford T. (eds) Encyclopedia of Personality and Individual Differences. Springer, Cham. https://doi.org/10.1007/978-3-319-28099-8_1162-1

[35] Lim, H. J., Min, D. K., Thorpe, L., Lee, C. H. (2016). Multidimensional construct of life satisfaction in older adults in Korea: a six-year follow-up study. BMC Geriatrics, 16:197. Retrieved https://bmcgeriatr.biomedcentral.com/articles/10.1186/s12877016-0369-0 DOI 10.1186/s12877-016-0369-0

[36] López-Ortega, M., Torres-Castro, S. \& Rosas-Carrasco, O. (2016) Psychometric properties of the Satisfaction with Life Scale (SWLS): secondary analysis of the Mexican Health and Aging Study. Health Qual Life Outcomes 14, 170. https://doi.org/10.1186/s12955-016-0573-9

[37] Lothian K, Philp I. Maintaining the dignity and autonomy of older people in the healthcare setting. BMJ. 2001;322(7287):668-670. doi:10.1136/bmj.322.7287.668

[38] Mallari, R. B. (2011). Successful Aging and Life Satisfaction of Older Filipinos: Evidence from the Philippine Longitudinal Study of Aging 2007. University of the Philippines. Retrieved from https://www.researchgate.net/profile/Ruzzel_Mallari/publication/3 22314592_Successful_Aging_and_Life_Satisfaction_of_Older_Fil ipinos_Evidence_from_the_Philippine_Longitudinal_Study_on_A ging_2007/links/5a5374be458515e7b72eacb9/Successful-Agingand-Life-Satisfaction-of-Older-Filipinos-Evidence-from-thePhilippine-Longitudinal-Study-on-Aging-2007.pdf

[39] Niemiec, C. P., \& Ryan, R. M. (2009). Autonomy, competence, and relatedness in the classroom: Applying self-determination theory to educational practice. Theory and Research in Education, 7, 133-144.

[40] Ogena, N. (2006). The low and slow ageing in the Philippines: auspicious or challenging? University of the Philippines Population Institute. Retrieved from https://www.researchgate.net/publication/252845207_The_Low_a nd_Slow_Ageing_in_the_Philippines_Auspicious_or_Challenging
[41] Ordudari, M. (2007). Translation procedures, strategies and methods. Translation Journal, Vol. 11;3. https://translationjournal.net/journal/41 culture.htm

[42] Parkar, S. R. (2015). Elderly mental health: needs. Mens sana monographs, 13(1), 91-99. Retrieved from https://www.ncbi.nlm.nih.gov/pmc/articles/PMC4381326/ DOI:10.4103/0973-1229.153311

[43] Pavot, W., and Diener, E. (1993). Review of the Satisfaction With Life Scale. Psychological Assessment 5(2):164-172. DOI: 10.1037/1040-3590.5.2.164

[44] Prasoon, R. \& Chaturvedi, K. R. (2016). Life satisfaction: a literature review. The Researcher-International Journal of Management Humanities and Social Sciences, 1(2). Retrieved from http://theresearcherjournal.org/pdfs/01021220163.pdf

[45] Ra, J. M., An, S., \& Rhee, K. J. (2013). The relationship between psychosocial effects and life satisfaction of the Korean elderly: Moderating and mediating effects of leisure activity. Journal of Arts and Humanities, Vol. 2, No. 11. Retrieved from https://www.theartsjournal.org/index.php/site/article/download/22 9/196 DOI: http://dx.doi.org/10.18533/journal.v2i11.229

[46] Ryan, R. M. \& Deci, E. banja. (2000). Self-determination theory and the facilitation of intrinsic motivation, social development, and well-being. American Psychological Association, Vol. 55, No. 1, 68-78. Retrieved from https://selfdeterminationtheory.org/SDT/documents/2000_RyanDe ci_SDT.pdf DOI: 10.1037//0003-066X.55.1.68

[47] Ryan, R. M. (1993). Agency and organization: Intrinsic motivation, autonomy and the self in psychological development. In J. Jacobs (Ed.), Nebraska symposium on motivation: Developmental perspectives on motivation (Vol. 40, pp. 1-56). Lincoln: University of Nebraska Press.

[48] Self-determination Theory. (2019). Retrieved from http://selfdeterminationtheory.org/theory/

[49] Tajrishi, K. Z., Besharat, M. A., Pourbohlool, S., \& Larijani, R. (2011). Psychometric properties of a Farsi version of the basic needs satisfaction in general scale in a sample of Iranian population. Procedia-Social and Behavioral Sciences 30, 221-225. Retrieved

from https://www.sciencedirect.com/science/article/pii/S187704281101 8696 https://doi.org/10.1016/j.sbspro.2011.10.044

[50] Vansteenkiste, M., \& Ryan, R. M. (2013). On psychological growth and vulnerability: Basic psychological need satisfaction and need frustration as a unifying principle. Journal of Psychotherapy Integration, 3, 263-280. Retrieved from http://selfdeterminationtheory.org/wpcontent/uploads/2014/07/2013_VansteenkisteRyan_JOPI2.pdf DOI: $10.1037 / \mathrm{a} 0032359$

[51] Ward, L., Barnes, M., \& Gahagan, B. (2012). Well-being in old age: findings from participatory research. Brighton: University of Brighton, Age Concern Brighton, Hove and Portslade. Retrieved from https://www.brighton.ac.uk/_pdf/research/ssparc/wellbeingin-oldage-full-report.pdf

[52] World Health Organization. (2015). World report on ageing and health. Retrieved from http://www.who.int/ageing/events/worldreport-2015launch/en/

[53] World Health Organization. (2018). Ageing and health. Retrieved from https://www.who.int/news-room/fact-sheets/detail/ageingand-health 